Напротив, октан активно участвует в процессе фотоокисления, который, по-видимому, сенсибилизируется 3,4-бензпиреном $\left[{ }^{2}\right]$; значительнал часть энергии ультрафиолетового излучения расходуется при этом на преврашение растворителя, а не растворенного вецества. В случае же ацетона на разложение последнего, по-видимому, также расходуется известная доля подводимой энергии, но получаемые при этом продукты обладают высокой реакционной способностью и ускоряют процесс превращения бензпирена, содействуя повышению эффективности суммарного процесса фотолиза.

ЛИТЕРАТ УРА

1. П а а льме Л., Г убергриц М., Изв, АН ЭССР, Хим. Геол,, 16, № 1, 32 (1967).

2. Паальме Л., Губергриц М., Изв. АН ЭССР, Хим. Геол., 17, № 2, 99 (1968).

3. Аллен А. О., Радиационная химия воды и водных растворов. М., 1963.

4. B a xendale J. H., B ridge N. K., J. Phys. Chem., 59, No, 8, 787 (1955).

5. Parker C. A., Proc. Roy. Soc., A 220, 104 (1953).
Институт химии
Академии наук Эстонской ССР
Поступила в $е$ редакцию
21/VI 1968

EESTI NSV TEADUSTE AKADEEMIA TOIMETISED. XVII KÖIDE
KEEMIA * GEOLOOGIA. 1968, Nr. 4

ИЗВЕСТИЯ АКАДЕМИИ НАУК ЭСТОНСКОП ССР. ТОМ ХVII
ХИМИЯ

К. ЛЭЭТС, А. ЭРМ, Э. ЛИППМАА, Ю. ПУСКАР

\title{
О СОСТАВЕ ПРОДУКТА РЕАКЦИИ ТЕЛОМЕРИЗАЦИИ ИЗОПРЕНА С УКСУСНОЙ КИСЛОТОЙ
}

K. LAATS, A. ERM, E. LIPPMAA, I. PUSKAR. ISOPREENI JA AADIKHAPPE TELOMERISATSIOONIPRODUKTI KOOSTISEST

א. LAATS, A. ERM, E. LIPPMAA, J. PUSKAR. ON THE COMPOSITION OF THE ISOPRENE AND ACETIC ACID TELOMERIZATION PRODUCT

Исследовались спектры ядерного магнитного двойного резонанса (ЯМДР) высокого разрешения препаративно выделенных фракций монотерпеновых оксипроизводных (пикн 8, 9 и 17 на хроматограмме, приведенной в [1 ]) в виде $20 \%$-ного раствора в четыреххлористом углероде с прибавкой $1-3 \%$ тетраметилсилана в качестве внутреннего стандарта. Спектры были сняты на универсальном спектрометре ЯМР [2] при комнатной температуре, на частоте 40 Мгц. Выяснилось, что данные фракции являются продуктами нерегулярного присоединения кар-1 бониевого иона к изопрену в положениях 3 и 4 .

Вещество (пик 8): 2,7-диметилоктадиен-1,6-ол-3, т. кип. $76-78^{\circ}$ (5 мм рт. ст.), $n_{D}{ }^{20} 1,4676, d_{4}{ }^{20} 0,8770$, чистота не менее $95 \%$, химические сдвиги протонов в миллионных долях и число протонов соответствующих групп: 


$$
\begin{gathered}
-\mathrm{C}=\mathrm{CH}-\frac{5,03}{1}, \quad \mathrm{CH}_{2}=\mathrm{C}-\frac{4,73}{2}, \quad=\stackrel{\mathrm{C}-\mathrm{I}}{\mathrm{C}}-\mathrm{O}-\frac{3,88}{1}, \\
-\mathrm{OH} \frac{3,05}{1}, \quad-\mathrm{CH}_{2}-\stackrel{\mathrm{C}}{\mathrm{C}}=\text { и } \quad-\mathrm{CH}_{2}-\mathrm{C}-\mathrm{O}-\frac{1,7-2,0}{4}, \quad \mathrm{CH}_{3}-\mathrm{C}=\frac{1,66}{9} .
\end{gathered}
$$

Вещество (пик 9): 2,6-диметил-3-гидроксиметилен-гептадиен-1,5 (лавандулол), т. кип. $77-79^{\circ}(5$ мм рт. ст. $), n_{D}{ }^{20} 1,4706$, чистота не менее $80 \%$, химические сдвиги и число протонов:

$$
\begin{gathered}
-\stackrel{\mathrm{C}}{\mathrm{C}}=\mathrm{CH}-\frac{5,04}{1}, \quad \mathrm{CH}_{2}=\mathrm{C}-\frac{4,75}{2}, \quad-\mathrm{CH}_{2}-\mathrm{O}-\frac{3,38}{2}, \\
-\mathrm{OH} \frac{2,80}{1}, \quad \stackrel{\mathrm{I}}{\mathrm{CH}}-\frac{2,0-2,15}{1}, \quad-\mathrm{CH}_{2}-\frac{2,08}{2}, \quad \mathrm{CH}_{3}-\stackrel{!}{\mathrm{C}}=\frac{1,67}{9} .
\end{gathered}
$$

Вещество (пик 17): 2,7-диметилоктадиен-2,6-ол-1, т. кип. 88-92 (5 мм рт. ст.), $n_{D}{ }^{20} 1,4758$, чистота не менее $85 \%$, химические сдвиги и число протонов:

$$
\begin{gathered}
-\mathrm{O}-\underset{\mid}{\mathrm{C}}-\stackrel{\mid}{\mathrm{C}}=\mathrm{CH}-\frac{5,31}{1}, \quad \stackrel{\mathrm{C}}{\mathrm{C}}=\mathrm{CH}-\frac{5,03}{1}, \quad-\mathrm{CH}_{2}-\mathrm{O}-\frac{3,85}{2}, \\
-\mathrm{OH} \frac{3,33}{1}, \quad-\mathrm{CH}_{2}-\mathrm{C}=\frac{1,97}{4}, \quad \mathrm{CH}_{3}-\stackrel{+}{\mathrm{C}}=\frac{1,62}{9} .
\end{gathered}
$$

Определенная нами структура фракций 1 и 3 была дополнительно доказана аллильной изомеризацией выделенного 2,7-диметилоктадиен1,6-ола-3 в 2,7-диметилоктадиен-2,6-ол-1.

\section{Л ИТ Е Р А Т У Р А}

1. Эр м А., Л ээтс К., Изв. АН ЭССР, Хим. Геол., 16, № 1, 37 (1967).

2. С юг и с А., Л ип п м а Э., Изв. АН ЭССР, Физ. Матем., 16, № 1, 81 (1967).

Институт химии и Институт кибернетики Академии наук Эстонской ССР
Поступила в редакцию 3/VII 1968 